\title{
Bioactive Compounds from Mangrove Endophytic Fungus and Their Uses for Microorganism Control
}

\author{
Rafael Dorighello Cadamuro ${ }^{1}$, Isabela Maria Agustini da Silveira Bastos ${ }^{1}$, Izabella Thais Silva ${ }^{1,2}$ (D), \\ Ariadne Cristiane Cabral da Cruz ${ }^{1,3}$, Diogo Robl ${ }^{1}$ (D) , Louis Pergaud Sandjo ${ }^{4}\left(\mathbb{D}\right.$, Sergio Alves, Jr. ${ }^{5}$, \\ Jose M. Lorenzo ${ }^{6,7, *(\mathbb{D})}$, David Rodríguez-Lázaro ${ }^{8}\left(\mathbb{D}\right.$, Helen Treichel ${ }^{9} \mathbb{D}$, Mário Steindel ${ }^{1}(\mathbb{D}$ \\ and Gislaine Fongaro $1, * \mathbb{D}$
}

check for updates

Citation: Cadamuro, R.D.; da Silveira Bastos, I.M.A.; Silva, I.T.; da Cruz, A.C.C.; Robl, D.; Sandjo, L.P.; Alves, S., Jr.; Lorenzo, J.M.;

Rodríguez-Lázaro, D.; Treichel, H.; et al. Bioactive Compounds from Mangrove Endophytic Fungus and Their Uses for Microorganism Control. J. Fungi 2021, 7, 455. https:/ / doi.org/10.3390/jof7060455

Academic Editor: Arianna Tavanti

Received: 14 May 2021

Accepted: 3 June 2021

Published: 7 June 2021

Publisher's Note: MDPI stays neutral with regard to jurisdictional claims in published maps and institutional affiliations.

Copyright: (c) 2021 by the authors. Licensee MDPI, Basel, Switzerland. This article is an open access article distributed under the terms and conditions of the Creative Commons Attribution (CC BY) license (https:// creativecommons.org/licenses/by/ $4.0 /)$.
1 Department of Microbiology, Immunology, and Parasitology, Federal University of Santa Catarina, Florianópolis 88040-900, SC, Brazil; rafaelcada@hotmail.com (R.D.C.); isabelamaria646@gmail.com (I.M.A.d.S.B.); izabella.thais@ufsc.br (I.T.S.); ariadne.cruz@ufsc.br (A.C.C.d.C.); diogo.robl@ufsc.br (D.R.); msteindel@gmail.com (M.S.)

2 Department of Pharmaceutical Sciences, Federal University Santa Catarina, Florianopolis 88040-900, SC, Brazil

3 Department of Dentistry, Federal University of Santa Catarina, Florianópolis 88040-900, SC, Brazil

4 Department of Chemistry, Federal University of Santa Catarina, Florianópolis 88040-900, SC, Brazil; p.l.sandjo@ufsc.br

5 Laboratory of Biochemistry and Genetics, Federal University of Fronteira Sul, Chapecó 89802-112, SC, Brazil; slalvesjr@gmail.com

6 Centro Tecnológico de la Carne de Galicia, Avd. Galicia n 4, Parque Tecnológico de Galicia, San Cibrao das Viñas, 32900 Ourense, Spain

7 Área de Tecnología de los Alimentos, Facultad de Ciencias de Ourense, Universidad de Vigo, 32004 Ourense, Spain

8 Microbiology Division, Faculty of Sciences, University of Burgos, 09001 Burgos, Spain; drlazaro@ubu.es

9 Laboratory of Microbiology and Bioprocess, Federal University of Fronteira Sul,

Erechim 99700-000, RS, Brazil; helentreichel@gmail.com

* Correspondence: jmlorenzo@ceteca.net (J.M.L.); gislainefongaro@gmail.com (G.F.); Tel.: +34-9885-48277 (J.M.L.); +55-49-9825-6993 (G.F.)

Abstract: Mangroves are ecosystems with unique characteristics due to the high salinity and amount of organic matter that house a rich biodiversity. Fungi have aroused much interest as they are an important natural source for the discovery of new bioactive compounds, with potential biotechnological and pharmacological interest. This review aims to highlight endophytic fungi isolated from mangrove plant species and the isolated bioactive compounds and their bioactivity against protozoa, bacteria and pathogenic viruses. Knowledge about this type of ecosystem is of great relevance for its preservation and as a source of new molecules for the control of pathogens that may be of importance for human, animal and environmental health.

Keywords: biotechnology; biodiversity; new drugs; health; pathogen control

\section{Introduction}

The extensive and continued use of natural products in popular medicine may be considered an indicator that they contain bioactive molecules with the potential to be transformed into new therapeutic agents for use in the treatment of diseases [1]. There are many examples of medicines (antibiotics, antiviral, anti-fungal, anti-parasitic, anti-tumoral, anticholesterolemic, anti-hypertensive, among others) from natural products, notably from higher plants, microorganisms and animals, among the best-sellers worldwide. According to Cragg and Newman [2,3], from the 1562 drugs approved by the FDA between 1981 and 2014, around $525(33.7 \%)$ were natural products or natural product derivatives. The use of natural products in the drug discovery process and development has some clear advantages: they represent chemical novelties when compared with other sources, leading 
to new drug candidates for complex targets [4,5]. By contrast, access to natural biological resources by lack of government legislation sometimes makes it challenging to use naturally derived molecules as a source of new medicines. However, naturally derived constituents have an extraordinary chemical diversity, compared to any collection of synthetic chemicals, and despite having differences such as complex two-dimensional and three-dimensional structures, pharmacological target, selectivity, behavior and resistance, they are capable of being absorbed and metabolized in the body [6].

The search for new bioactive compounds is three-fold: (i) find molecules that may control diseases that no synthetic drug has been shown to be capable of, (ii) discover alternative compounds that provoke fewer side-effects and lower multi-drug resistance over the microbiomes and (iii) replace synthetic drugs to mitigate environmental impacts caused by their presence in soil and bodies of water [6-8]. Natural products obtained from microorganisms (microbial products) are generally used for the treatment of diseases caused by bacteria, fungi, protozoa and viruses. Microorganisms have stood out in the production of new natural products. Out of the 23,000 existing microbial compounds with antimicrobial and anti-infectious activities, $42 \%$ are produced by fungi and $32 \%$ by filamentous bacteria, the actinomycetes [9].

The production of antibiotics began with the discovery of penicillin at the end of the 1920s [10,11]. After the 1980s, pharmaceutical companies began to lose interest in the development of new compounds, as each new discovery takes years of development, requires both pre-clinical and clinical studies and has a short window of time for organizations to sell the products before the expiration of the patent. The most intensive use of classical antibiotics occurred in the era of antibiotics (1940-1962), so new antibiotics are necessary for the treatment of diseases since pathogens in their great majority can create resistance to old natural products, while some have this resistance naturally, such as Pseudomonas aeruginosa [9]. The search for new compounds for drug production is challenging. The screening of new compounds requires a lot of knowledge, scientific experience and the use of technology [12].

The mangrove ecosystem is an attractive biodiversity hotspot for prospecting new useful bioactive and chemical scaffolds, including those with potential medicinal application. Overall, in the past two decades, mangrove-associated bacteria/fungi have gained considerable attention due to their unique ecological characteristics, diversity and abundance of novel bioactive secondary metabolites, as demonstrated by the growth in the number of publications in the literature $[13,14]$. Mangrove forests are composed mainly of shrubs and trees of the Rhizophoraceae, Acanthaceae, Lythraceae, Verbenaceae, Combretaceae and Arecaceae families [14]. In Brazil, mangroves are classified as red, white or black mangroves according to some of these families: Rhizophora mangle (Rhizophoraceae) [15], Laguncularia racemosa (Combretaceae) [15] and Avicennia schaueriana (Verbenaceae) [16], respectively. These species can be found mainly in the city of Florianópolis, which is the capital city of the state of Santa Catarina, and is located on an island, together with the species Spartina densiflora and Spartina alterniflora weeds. In the transitional forest area, there are also species such as Hibiscus pernambucensis and Acrostichum danaeaefolium, commonly known as "mangrove cotton" and "mangrove fern" [17].

The endemic mangrove flora represents a great source of molecules with biological potential produced by plant biosynthesis, microbial interaction and cohabitation with other species [18]. Beyond this, mangroves have fauna rich in aquatic animals (fish, amphibians and reptiles) and land animals (mammals and birds). These animals take advantage of mangrove forests for their essential life cycle activities, and their breeding and reproducing cycles provide a rich source of food for humans [19].

Mangrove forest is a refuge for several microorganisms, such as fungi, bacteria and algae. In this review, we focused on endophytic fungi from mangrove ecosystems as a potential source of new natural products with biotechnological and pharmaceutical applications. Moreover, methodologies used for the isolation of these microorganisms are also presented. 
Endophytic fungi isolated from mangrove plants and mangrove soils were first described by Cribb [20]. Since then, several studies on these marine fungi have been conducted along the coast of the Indian, Pacific and Atlantic oceans. These fungi comprise the second-largest ecological group of marine fungi. They have unique morphological structures and physiological mechanisms for the survival of host plants in adverse environmental conditions, such as the ability to grow in high salt concentrations through endophyte-host interactions [21].

Many of the physiological mechanisms of endophytic-host interaction are still poorly understood and established, mainly those related to the evolutionary and genetic mechanisms of the endophytes. It is supposed that the endophytic species have often evolved from plant pathogenic ancestors, and that this interaction can range from parasitism to mutualism, which depends mainly on the fungi species, the genetic background of the host and the environment where these microorganisms are found [22].

\section{Endophytic Fungi}

Endophytic fungi are phylogenetically characterized as belonging to the Ascomycota, Basidiomycota and Zygomycota phyla [23]. The ascomycetes of the genus Trichoderma, reported in the literature in the last ten years, were first isolated from mangrove areas of Brazil, China and Indonesia in 1920 (Table 1). Known as a biocontrol agent against pathogens of cultivated plants, Trichoderma spp. also present an increased capacity of degradation of some toxic compounds present in plants, soil and water [24]. Trichoderma spp. colonizes its hosts quickly, producing a large number of green spores of free life, and has fruiting bodies that assist in the fungal characterization of this genus [25].

Zygomycetes of Rhizopus genera isolated in a mangrove area of Nigeria (Table 1) is also a filamentous fungus that presents branched mycelium bodies. It is mainly used in traditional food fermentation processes and as a source of enzymes for degradation of organic pollutants [26,27]. The filamentous fungi Schizophyllum commune, isolated from the Indian mangrove forest (Table 1), belongs to the basidiomycete phylum. It has fruiting bodies (which facilitate its characterization) and whitish to light greyish/brown colonies. It is used in pigment production and has antiviral and anticancer capacities [28].

The diversity of endophytic fungi has been studied mainly on barks, branches, leaves, stems and roots of mangrove plant taxa in many countries around the world in order to identify their biological activities. It is noteworthy that China is the country with the highest number of endophytic fungi isolated from mangrove plants. Ascomycetes, belonging to the Alternaria, Ascomycota, Aspergillus, Campylocarpon, Cladosporium, Colletotrichum, Cytospora, Daldinia, Diaporthe, Dothiorella, Emericella, Eupenicillium, Eurotium, Guignardia, Glomerella, Lasiodiplodia, Leptosphaerulina, Neosartorya, Nodulisporium, Nigrospora, Penicillium, Pestalotiopsis, Phoma, Phomopsis, Phyllosticta, Pleosporales, Stemphylium, Talaromyces, Trichoderma and Xylaria genera, and the basidiomycete Phellinus noxius, were the most frequently found (Table 1).

In Brazil, endophytic ascomycetes of the Colletotrichum, Glomerella, Guignardia, Nodulisporium, Phomopsis and Phyllosticta genera were isolated in a mangrove area of the island of Itamaracá in the state of Pernambuco [29]. Isolations have also occurred in the Cananeia and Bertioga mangrove forests in the coast of the state of São Paulo, with the predominance of ascomycetes of the Colletotrichum, Diaporthe, Fusarium, Trichoderma and Xylaria genera [30]. More recently, ascomycetes from the Aspergillus, Fusarium, Penicillium and Trichoderma genera have been isolated from a mangrove area in the city of Canavieiras, in the state of Bahia [31]. Thus, considering the vast coastal extension of Brazil with different ecosystems, with a distance between Bahia and Santa Catarina higher than $1.900 \mathrm{~km}$, for example, this way, there are few studies of endophytic fungi from mangrove plants. 
Table 1. Endophytic fungi isolated from mangrove plants worldwide.

\begin{tabular}{|c|c|c|}
\hline Endophytic Fungi & Mangrove Plant & Reference \\
\hline Acremonium sp. and Acremonium strictum & Rhizophora apiculata & {$[32,33]$} \\
\hline Alternaria longipe & Avicennia officinalis & [34] \\
\hline Alternaria sp. & Myoporum bontioides, Rhizophora mucronata & {$[35,36]$} \\
\hline Ascomycota sp. & Pluchea indica & [37] \\
\hline Aspergillus clavatus & Myoporum bontioides & [38] \\
\hline Aspergillus flavipes & Acanthus ilicifolius & [39] \\
\hline Aspergillus flavus & Hibiscus tiliaceus, Sonneratia griffithii, Kandelia obovata & [40-42] \\
\hline Aspergillus fumigatus & Acrostichum specioum, Sonneratia griffithii & {$[41,43]$} \\
\hline Aspergillus nidulans & $\begin{array}{l}\text { Rhizophora stylosa } \\
\text { Sonneratifithi }\end{array}$ & {$[44,45]$} \\
\hline Áspergillus niger & Sonneratia apetala, S. griffithii & {$[41,46-48]$} \\
\hline Aspergillus sp. & $\begin{array}{c}\text { Bruguiera gymnorrhiza, Avicennia africana, Xylocarpus moluccensis, Acanthus ilicifolius, } \\
\text { Avicennia marina, Dalbergia ecastaphyllum }\end{array}$ & {$[31,49-53]$} \\
\hline Aspergillus tubingensis & Pongamia pinnata & [54] \\
\hline Aspergillus versicolor & Excoecaria agallocha & [55] \\
\hline Campylocarpon sp. & Sonneratia caseolaris & [56] \\
\hline Cladosporium sp. & $\begin{array}{c}\text { Rhizophora apiculata, Aegiceras corniculatum, Kandelia candel, Rhizophora mucronata, } \\
\text { Excoecaria agallocha }\end{array}$ & {$[36,52,57-59]$} \\
\hline Colletotrichum gloeosporioides & Avicennia schaueriana and Laguncularia racemosa, Ceriops tagal and Sonneratia apetala & {$[29,47,60]$} \\
\hline Colletotrichum sp. & $\begin{array}{l}\text { Xylocarpus granatum, Avicennia schaueriana Laguncularia racemosa and Rhizophora } \\
\text { mangle Aegiceras corniculatum. Avicennia africana. }\end{array}$ & {$[29,50,57]$} \\
\hline $\begin{array}{l}\text { Cytospora sp. } \\
\text { Daldinia eschscholtzii }\end{array}$ & $\begin{array}{l}\text { Ceriops tagal } \\
\text { Bruguiera sexangula var. rhynchopetala }\end{array}$ & {$[61]$} \\
\hline Diaporthe sp. & $\begin{array}{c}\text { Avicennia schaueriana, Laguncularia racemosa, and Rhizophora mangle, } \\
\text { Rhizophora stylosa }\end{array}$ & {$[30,63]$} \\
\hline Dothiorella sp. & Aegiceras corniculatum & [64] \\
\hline & Aegiceras corniculatum & [65] \\
\hline Epicoccum sp. & Avicennia africana & [50] \\
\hline Eupenicillium sp. & Xylocarpus granatum & [66] \\
\hline Eurotium & Rhizophora mucronata & [67] \\
\hline Eurotium rubrum & Hibiscus tiliaceu & [68] \\
\hline Fusarium equiseti & Sonneratia apetala & [47] \\
\hline Fusarit & Rhizophora mucronata & [36] \\
\hline Fusarium napiforme & Rhizophora mucronata & [69] \\
\hline Fusarium phyllophilum & Avicennia africana & [50] \\
\hline Fusarium sp. & $\begin{array}{l}\text { Avicennia schaueriana, Laguncularia racemosa, Rhizophora mangle, Rhizophora } \\
\text { mucronata and Dalberoia ecastaphyllum }\end{array}$ & {$[30,36,69]$} \\
\hline Glomerella cingulata and Guignardia sp. & Avicennia schaueriana, Laguncularia racemosa, Rhizophora mangle & [29] \\
\hline Guignardia camelliae & Avicennia sp. & [70] \\
\hline Guignardia sp. & Scyphiphora hydrophyllacea, Aegiceras corniculatum, Acanthus ilicifolius; & {$[59,71,72]$} \\
\hline Glomerella sp. & Aegiceras corniculatum & [59] \\
\hline Hypocrea & Premna serratifolia & [73] \\
\hline Lasiodiplodia theobromae & Acanthus ilicifolius, Avicennia lanata & {$[74,75]$} \\
\hline Leptosphaerulina sp. & Acanthus ilicifolius. & [76] \\
\hline Neosartorya hiratsukae & Avicennia sp. and Aricennia marina & {$[76,77]$} \\
\hline Nodulisporium gregarium & Avicennia schaueriana & [29] \\
\hline Nodulisporium sp. & Acanthus ilicifolius & [72] \\
\hline Nigrospora sp. & Kandelia candel, Pongamia pinnata, and Rhizophora mucronata & {$[36,78,79]$} \\
\hline Nigrospora sphaerica & Bruguiera gymnorrhyza & [79] \\
\hline Phellinus noxius & Acanthus ilicifolius & [72] \\
\hline Penicillium b & Avicennia marina & {$[80,81]$} \\
\hline Penicillium chrysogenum & Porteresia coarctata, Myoporum bontioides & {$[82,83]$} \\
\hline 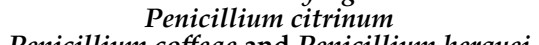 & Bruguiera sexangula var. rhynchopetala & {$[84,85]$} \\
\hline $\begin{array}{l}\text { Penicillium coffeae and Penicillium herquei } \\
\text { Penicillium simplicissimum }\end{array}$ & $\begin{array}{l}\text { Laguncularia racemosa } \\
\text { Bruouiera }\end{array}$ & {$[86,87]$} \\
\hline Penicillium spp. & $\begin{array}{l}\text { Bruguiera sexangula var. Rhynchopetala, Bruguiera gymnorrhiza, K. candel, Avicennia } \\
\text { africana. Dalbergia ecastaphyllum }\end{array}$ & {$[31,50,89-91]$} \\
\hline $\begin{array}{l}\text { Pestalotiopsis sp. } \\
\text { Pestalotiopsis vacinii }\end{array}$ & $\begin{array}{c}\text { Aegiceras corniculatum, Rhizophora mucronata, Rhizophora stylosa } \\
\text { Kandelia candel }\end{array}$ & {$[36,92-94]$} \\
\hline Phoma sp. & $\begin{array}{c}\text { Thespesia populneoide, Myoporum bontioides, Rhizophora mucronata, Kandelia sp., } \\
\text { Acanthus ilicifolius }\end{array}$ & {$[36,38,72,95]$} \\
\hline $\begin{array}{l}\text { Phomopsis archeri, P. diachenii } \\
\text { Phomopsis longicolla }\end{array}$ & $\begin{array}{c}\text { Avicennia schaueriana and Laguncularia racemosa } \\
\text { Brguiera sexangula var. rhynchopetala }\end{array}$ & {$[29]$} \\
\hline Phomopsis sp. & $\begin{array}{c}\text { Rhizophora apiculata, Kandelia candel, Acanthus ilicifolius, Xylocarpus granatum, } \\
\text { Avicennia africana }\end{array}$ & {$[50,96-98]$} \\
\hline Phyllosticta capitalensis & Bruguiera sexangula & [94] \\
\hline Phyllosticta sp. & $\begin{array}{c}\text { Acanthus ilicifolius, Avicennia alba, Ceriops decandra, Lumnitzera littorea, Rhizophora } \\
\text { apiculata, Rhizophora mucronata, Sonneratia alba, Xylocarpus moluccensis, } \\
\text { Rhizophora mangle }\end{array}$ & {$[28,57]$} \\
\hline Pleosporales sp. & Kandelia candel & [99] \\
\hline $\begin{array}{l}\text { Rhizopus sp. } \\
\text { Schizonhullum }\end{array}$ & $\begin{array}{l}\text { Avicennia africana } \\
\text { Avicennia fficinalis }\end{array}$ & {$[50]$} \\
\hline $\begin{array}{l}\text { Schizophyllum commune } \\
\text { Stemphylium sp. }\end{array}$ & $\begin{array}{l}\text { Avicennia officinalis } \\
\text { Bruguiera sexangula var. rhynchopetala }\end{array}$ & {$[101,102]$} \\
\hline Talaromyces sp. & Kandelia candel & [103] \\
\hline Talaromyces stipitatus & Acanthus ilicifolius & [98] \\
\hline Trichoderma sp. & $\begin{array}{c}\text { Avicennia schaueriana Laguncularia racemosa, Rhizophora mangle, Clerodendrum inerme, } \\
\text { Ceriops tagal, Bruguiera sp., Dalbergia ecastaphyllum }\end{array}$ & $\begin{array}{l}{[30,70,103,} \\
104]\end{array}$ \\
\hline Xylaria psidii & $\begin{array}{c}\text { Aegle marmelos } \\
\text { a }\end{array}$ & [104] \\
\hline Xylaria sp. & $\begin{array}{l}\text { Avicennia schaueriana, Laguncularia racemosa, Rhizophora mangle, Rhizophora } \\
\text { mucronata Xylocarpus granatum. Acanthus ilicifolius }\end{array}$ & {$[30,36,51,72]$} \\
\hline Zasmidium sp. & L. racemosa & {$[105,106]$} \\
\hline
\end{tabular}




\section{Bioactive Compounds from Mangrove Endophytic Fungus}

The main classes of endophytic fungal compounds isolated from mangrove areas and their pharmacological activities are presented in Table 2. The potential biological applications of metabolites produced by these fungi include growth inhibition of bacteria and protozoan and virus inactivation [106].

Saad [105] isolated endophytic fungi from root samples of Malva parviflora and leaf samples of Chenopodium album, Pelargonium graveolens and Melia azedarach. Nine fungi presented bioactivity and were identified using DNA-sequences, with five being isolated from C. album: Fusarium chlamydosporum, A. alternata saad5 MG786542, A. alternata saad8 MG786545, Fusarium oxysporum and Phoma sp. Two fungi were isolated from M. azedarach: F. equiseti and Stemphylium sp., and two from the medicinal plant M. azedarach: C. lunata and Nigrospora sphaerica. The metabolites presented bioactivity against Spodoptera littoralis, a lepidopteran pest known to infect around 44 different families of hosts, such as cruciferous, legumes, grasses and deciduous fruit trees. Metabolites produced by the fungi Curvularia lunata and Alternaria solani demonstrated bioactivity, inhibiting $60 \%$ and $40 \%$ of larvae of Spodoptera littoralis, respectively.

It is expected that some of the endophytic-fungi extracts harbor bioactive compounds when the fungal cells have been grown in the presence of epigenetic regulators, which are able to modulate gene expression for secondary-metabolite synthesis [48,107-115]. Recently, Demers [116] showed that $72 \%$ of the analyzed mangrove fungi presented active extracts only when cultured in media containing histone deacetylase inhibitors (HDACi) and DNA methyltransferase inhibitors (DNMTi). In addition, those authors also showed that nearly $70 \%$ of the active extracts were selective to a single target organism. Thus, considering the specificity of each endophytic-fungi bioactive against different microorganisms, the effects of these compounds against protozoan, bacteria and virus are addressed below in separate subsections. 
Table 2. Chemical class of the main anti-protozoan, antibacterial and antiviral metabolites produced by mangrove endophytic fungi.

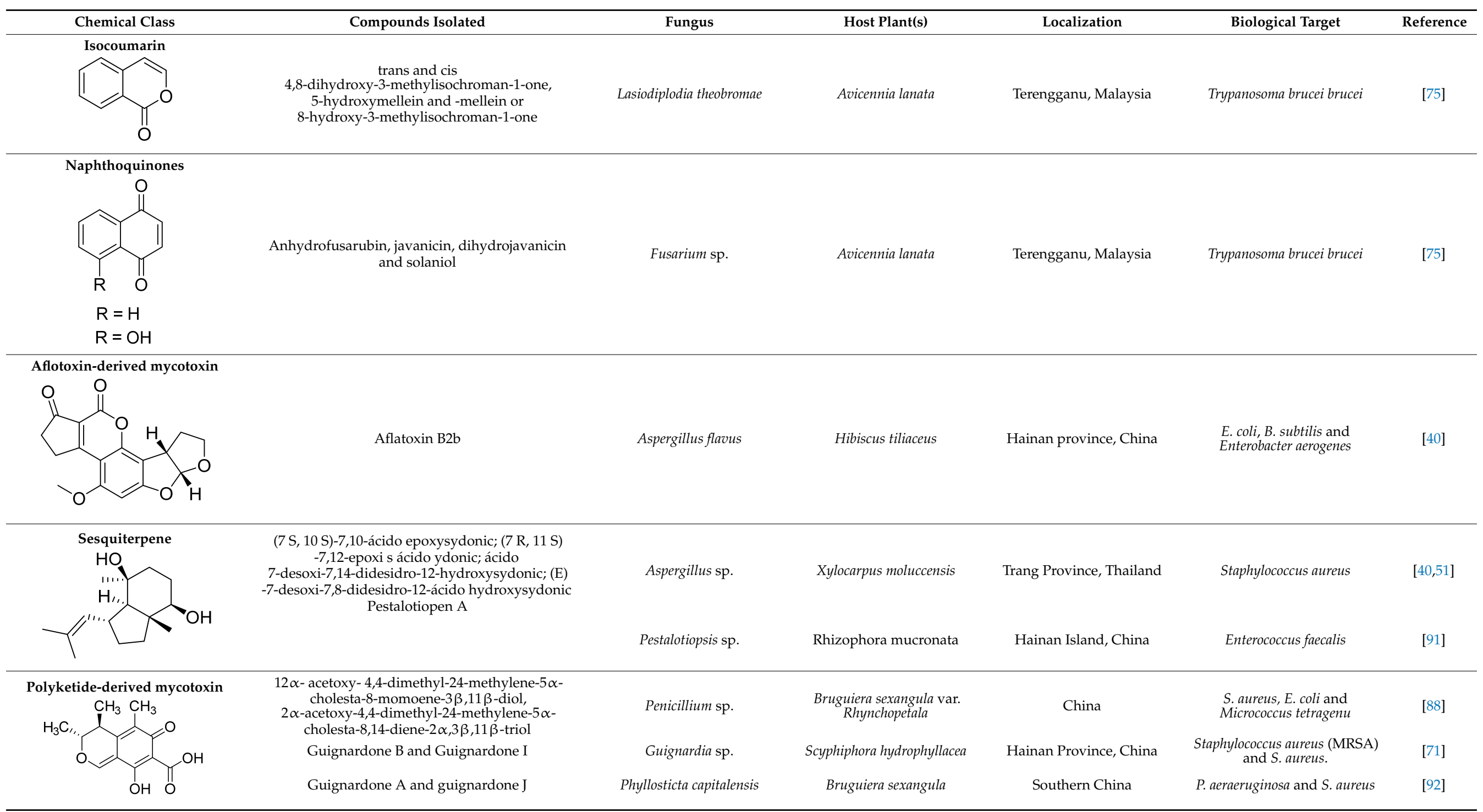


Table 2. Cont

\begin{tabular}{|c|c|c|c|c|c|c|}
\hline Chemical Class & Compounds Isolated & Fungus & Host Plant(s) & Localization & Biological Target & Reference \\
\hline & $\begin{array}{l}\text { Austinol } \\
\text { Bacillisporin A), bacillisporin B } \\
\text { and Penicisimpins A-C }\end{array}$ & Penicillium citrinum & $\begin{array}{l}\text { Bruguiera sexangula } \\
\text { var. rhynchopetala }\end{array}$ & South China & $\begin{array}{c}\text { S. aureus } \\
\text { S. epidermidis } \\
\text { Bacillus subtilis, Aeromonas } \\
\text { hydrophilia, Escherichia coli, } \\
\text { M. luteus, Pseudomonas } \\
\text { aeruginosa, V. alginolyticus, } \\
\text { V. harveyi and } \\
\text { V. parahaemolyticus }\end{array}$ & [85] \\
\hline & $\begin{array}{l}\text { Dichlorodiaportintone, } \\
\text { desmethyldichlorodiaportin, dichlorodiaportin } \\
\text { Spergillumarinas A and B } \\
\text { Penicimarins G and H } \\
\text { Pestalotiopisorin B }\end{array}$ & $\begin{array}{l}\text { Ascomycota sp. } \\
\text { Aspergillus sp. } \\
\text { Penicillium citrinum } \\
\text { Pestalotiopsis sp. }\end{array}$ & $\begin{array}{l}\text { Pluchea indica } \\
\text { Bruguiera gymnorrhiza } \\
\text { Bruguiera sexangula var. } \\
\text { rhynchopetala } \\
\text { Rhizophora stylosa }\end{array}$ & $\begin{array}{l}\text { Guangxi Province, China } \\
\text { SouthChina } \\
\text { Hainan Island, China }\end{array}$ & $\begin{array}{l}\text { S. aureus, B. subtilis, E. coli, } \\
\text { Klebsiella pneumoniae and } \\
\text { Acinetobacter calcoaceticus } \\
\text { S. aureus and B. subtilis } \\
\text { S. aureus, S. epidermidis, } \\
\text { Escherichia coli, Bacillus cereus } \\
\text { and Vibrio alginolyticus } \\
\text { E. coli and P. aeruginosa }\end{array}$ & $\begin{array}{l}{[37]} \\
{[49]} \\
{[85]} \\
{[93]}\end{array}$ \\
\hline one $\quad 0$ & $\begin{array}{l}\text { 8-dihydroxy-chromone, bacillisporin A and } \\
\text { bacillisporin B }\end{array}$ & Penicillium aculeatum & Kandelia candel & $\begin{array}{c}\text { Yangjiang, } \\
\text { Guangdong province, } \\
\text { China }\end{array}$ & B. subtilis and Salmonella spp. & [94] \\
\hline \multirow{6}{*}{ Anthraqu } & Isoversicolorin $C$, versicolorin $C$ & Aspergillus nidulans & Rhizophora stylosa & $\begin{array}{l}\text { Twig, Chanthaburi } \\
\text { Province, Eastern Thailand }\end{array}$ & $\begin{array}{l}\text { E. coli, M. luteus, V. vulnificus, } \\
\text { V. anguillarum, V. alginolyticus, } \\
\text { Ed. ictaluri, } \\
\text { V. parahaemolyticus } \\
\text { S. aureus and E. Faecalis }\end{array}$ & [45] \\
\hline & Diaportheins B and Emodin & Eurotium chevalier & $\begin{array}{l}\text { Rhizophora } \\
\text { Mucronata }\end{array}$ & Hainan Island, China & E. coli & [67] \\
\hline & $\begin{array}{l}\text { 9-dehydroxyeurotinone } \\
\text { Bostrycin, and Deoxybostrycin }\end{array}$ & $\begin{array}{l}\text { Eurotium rubrum } \\
\text { Nigrospora sp. }\end{array}$ & $\begin{array}{l}\text { Hibiscus tiliaceu } \\
\text { Kandelia candel }\end{array}$ & \multirow[t]{2}{*}{ South China } & $\begin{array}{c}\text { Staphylococcus aureus and } \\
\text { Escherichia coli } \\
\text { S.aureus, E.coli, } P \text { aeruginosa, } \\
\text { Sarcina ventriculi, B. subtilis }\end{array}$ & $\begin{array}{l}{[68]} \\
{[78]}\end{array}$ \\
\hline & 2'-acetoxy-7-chlorocitreorosein & Penicillium citrinum & $\begin{array}{l}\text { Bruguiera sexangula var. } \\
\text { rhynchopetala }\end{array}$ & & Vibrio parahaemolyticus & [84] \\
\hline & $\begin{array}{l}\text { 2R,3S)-7-ethyl-1,2,3,4-tetrahydro-2,3,8-trihydroxy-6- } \\
\text { methoxy-3-methyl-9,10-anthracenedione }\end{array}$ & Phomopsis sp. & Rhizophora apiculata & $\begin{array}{l}\text { Songkhla province, } \\
\text { Thailand }\end{array}$ & $\begin{array}{c}\text { Staphylococcus aureus } \\
\text { ATCC25923 and } \\
\text { methicillin-resistant S. aureus } \\
\text { SK1 }\end{array}$ & [96] \\
\hline & 2-O-acetylaltersolanol B, Altersolanols A and B & Stemphylium sp. & $\begin{array}{l}\text { Bruguiera sexangula var. } \\
\text { rhynchopetala }\end{array}$ & South China & E. coli, S. aureus and B. subtilis & [96] \\
\hline
\end{tabular}


Table 2. Cont.

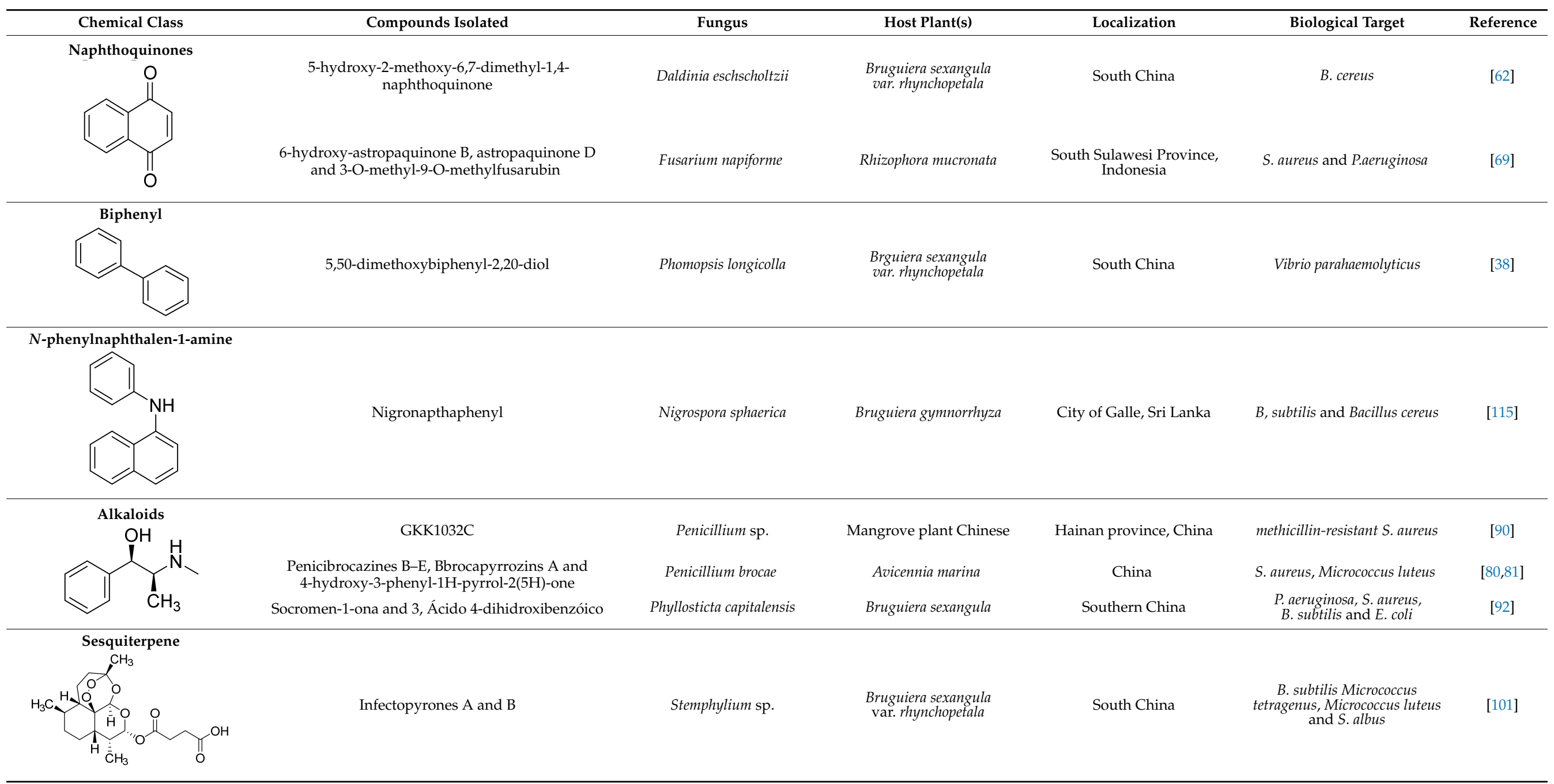


Table 2. Cont

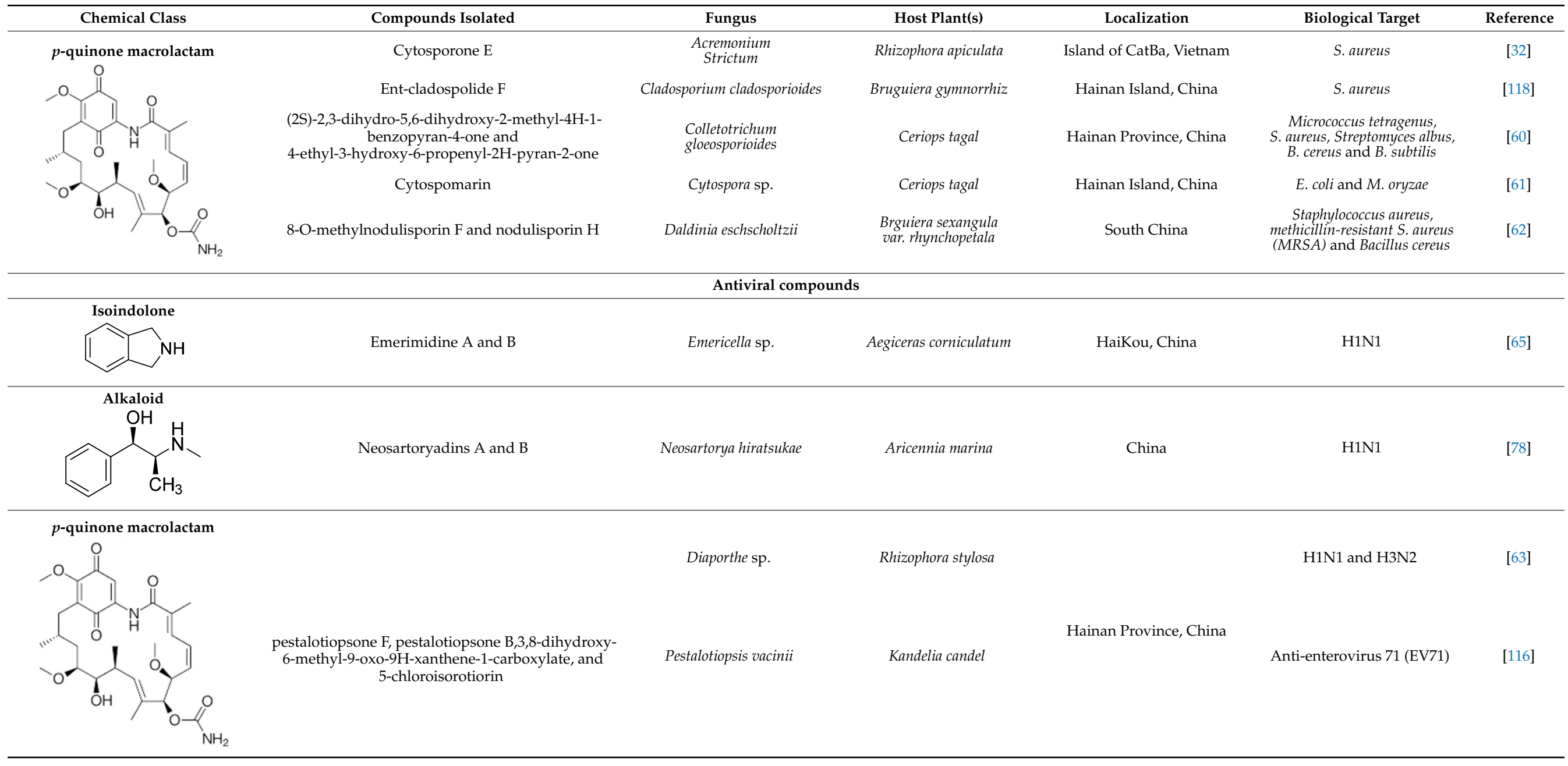




\subsection{Antiprotozoan}

Malaria is an example of a tropical disease caused by Plasmodium spp., which accounts for around 220 million cases of the disease and 435,000 deaths worldwide every year [87]. The emergence of strains of malaria resistant to synthetic classical drugs requires a continuous search for new compounds from alternative niches to introduce new and efficient products to the treatment [107].

The compound oxylipin, (9Z, 11E)-13-oxooctadeca-9,11-dienoic acid, produced by the fungus Penicillium herquei isolated from the mangrove plant Laguncularia racemosa, showed minimal anti-parasitic activity against Plasmodium falciparum (half-maximal inhibitory concentration, $\left.\mathrm{IC}_{50}>100 \mu \mathrm{M}\right)$, Trypanosoma brucei $\left(\mathrm{IC}_{50}>100 \mu \mathrm{M}\right)$, Leishmania donovani $\left(\mathrm{IC}_{50}>100 \mu \mathrm{M}\right)$ and Leishmania major $\left(\mathrm{IC}_{50}>100 \mu \mathrm{M}\right)$ [119]. Fortunately, other potentially bioactive compounds for Trypanosoma brucei have been investigated. Dihydroisocoumarins (trans and cis 4,8-dihydroxy-3-methylisochroman-1-one, 5-hydroxymellein and -mellein or 8-hydroxy-3-methylisochroman-1-one) and naphthoquinones (anhydrofusarubin, javanicin, dihydrojavanicin and solaniol) were produced by the fungi Lasiodiplodia theobromae and Fusarium sp. respectively, from the Malaysian mangrove plant Avicennia lanata (Table 2). These compounds showed significant activity against Trypanosoma brucei brucei with $\mathrm{IC}_{50}$ values of $0.32-12.5 \mu \mathrm{M}$ [75].

It is worth noting that the bioprospection of bioactive compounds against protozoan must take into account their cytotoxicity for the protozoan host cells [120]. Among thirty-four active fungal extracts assayed against the amoeba Naegleria fowleri, by Demeres et al. [121], two were detected with high cytotoxicity on the J774 macrophage cell line $\left(\mathrm{IC}_{50}<5 \mu \mathrm{g} / \mathrm{mL}\right)$. For Leishmania donovani infecting the same macrophage lineage, those authors found 562 extracts active at $10 \mu \mathrm{g} / \mathrm{mL}$ or less. However, when they established a criterium for high antiparasitic activity $\left(\mathrm{IC}_{50}<1.0 \mu \mathrm{g} / \mathrm{mL}\right.$ ) and low cytotoxicity $\left(\mathrm{J} 774 \mathrm{IC}_{50}>5 \mu \mathrm{g} / \mathrm{mL}\right)$, only 116 remained. Besides, $64 \%$ of these 116 extracts were found when the endophytic fungal strains were grown under the influence of epigenetic modulators [121]. By contrast, these cytotoxic compounds may be useful for cancer and tumor treatments [119,121-123].

The trypanosomatid Trypanosoma cruzi is the etiologic agent of Chagas disease. Although only about $10 \%$ of people infected are diagnosed, it has been estimated that $6-$ 7 million people worldwide (endemic in Latin America) may be infected with T. cruzi, putting over 70 million people at risk [124]. In this sense, bioprospection of trypanocidal molecules is of undoubted interest to public health, mostly because Chagas disease is considered a neglected tropical disease, as pharmaceutical companies do not normally show interest in it. Fortunately, extracts of endophytic fungi have shown promising results, with high activity against trypanosomatids [87,121]. Ferreira [120] showed that extracts of the endophytic fungi Diaporthe cf. mayteni and Endomelanconiopsis endophytica have high trypanocidal activity against amastigote forms of T. cruzi. In another study of the same group, ophiobolin K and 6-epi-ophiobolin K (two bioactive compounds) were isolated from Aspergillus calidoustus and shown to be effective against this trypanosomatid [122]. However, despite being a promising approach to fight Chagas disease, there is still a lack of specific studies on mangrove-isolated endophytes against T. cruzi.

\subsection{Antibacterial}

Animal management is essential for the improvement of livestock. Nonetheless, this interaction led to the appearance of several foodborne diseases $[125,126]$. Diseases that can spread among several different animal species affecting are defined as zoonotic diseases. Among the groups of bacteria, zoonotic enterobacteria are highlighted for possessing resistance to $\mathrm{pH}$ and temperature variations [127]. One factor that influences the low efficiency of pesticides in agriculture is the large-scale administration of synthetic antibiotics to the healthcare of humans and animals, which also has a role in selecting plasmids of resistance to synthetic chemicals [128-130].

In this sense, the search for alternatives such as endophytic fungi bioactive compounds may overcome the bacterial resistance problem, and consequently mitigate the environmental 
impact caused by high amounts of inefficient pesticides. Aflatoxin B2b mycotoxin produced by Aspergillus flavus associated with Chinese mangrove plant Hibiscus tiliaceus (Table 2) showed antibacterial activity against Escherichia coli, Bacillus subtilis and Enterobacter aerogenes, with $\mathrm{IC}_{50}$ values of 22.5, 1.7 and $1.1 \mu \mathrm{M}$ [40]. In addition, sesquiterpenoids compounds (Table 2), isolated from an Aspergillus spp. strain found at Xylocarpus moluccensis, presented moderate antibacterial activities against Staphylococcus aureus, with $\mathrm{IC}_{50}$ values from 31.5 to $41.9 \mu \mathrm{M}$ [51].

Another compound was isolated from Pestalotiopsis sp. present in the leaves of Rhizophora mucronata and collected in the region of Dong Zhai Gang-Mangrove Garden on Hainan Island, China. This compound possesses a novel hybrid sesquiterpene-cyclo-paldic acid metabolite with an unusual carbon skeleton, called pestalotiopisorin A. Antibacterial activity was evaluated against Enterococcus faecalis, showing moderate results [91] (Table 2). The tetracyclic triterpenoids $12 \alpha$-acetoxy-4,4-dimethyl-24-methylene- $5 \alpha$-cholesta8-momoene-3 $\beta, 11 \beta$-diol, $12 \alpha$-acetoxy-4,4-dimethyl-24-methylene-5 $\alpha$-cholesta-8,14-diene$2 \alpha, 3 \beta, 11 \beta$-triol, and meroterpernoids Guignardone B, Guignardone I, Guignardone A and Guignardone J, isolated from the fungi Guignardia sp and Phyllosticta capitalensis, were also investigated for inhibitory activity against several bacteria, such as S. aureus, E. coli, Micrococcus tetragenu and Pseudomonas aeruginosa (Table 2) [131].

A new isocoumarin derivative (pestalotiopisorin B), isolated from the endophytic fungus Pestalotiopsis sp., was shown to be active against $P$. aeruginosa, methicillin-resistant S. aureus, B. subtilis and E. coli. The fungus was isolated from Rhizophora stylosa, a plant present in a mangrove area of China [94]. Numerous compounds were also obtained from the culture of Ascomycota sp. found on Pluchea indica, collected in Shankou Mangrove Nature Reserve in the Guangxi Province, China. The obtained compounds showed antibacterial activity against the Gram-positive S. aureus and B. subtilis, and the Gramnegative E. coli, K. pneumoniae and Acinetobacter calcoaceticus. These compounds were identified as dichloroisocoumarins-dichlorodiaportintone, desmethyldichlorodiaportin and dichlorodiaportin [83].

Kandelia candel is a plant spread in Guangdong province, China, a host of Guignardia sp., which produces Guignardins B and palmarumycin BG1. Among them, Guignardins B presented antibacterial activity against $E$. faecalis ATCC 29,212 and another one against Aeromonas hydrophila ATCC 7966 [131]. Heritiera fomes is a mangrove plant located in the region of Sundarbans, India. The endophyte isolated from it is Pestalotia spp., which produces oxysporone, a compound containing a $4 \mathrm{H}$-furo(2,3-b)pyran-2(3H)-one structure, and xylitol, a molecule with five-carbon sugar alcohol. Both compounds demonstrated efficiency against methicillin-resistant S. aureus (MRSA) strains ATCC 25,923, RN4220, EMRSA-15, EMRSA-16, SA-1199B and XU2, with $\mathrm{IC}_{50}$ values ranging between 32 and $128 \mu \mathrm{g} / \mathrm{mL}$ [48].

\subsection{Antiviral}

The viruses are intracellular-dependent, and are always necessary for the invasion and kidnap of cellular machinery to replication. Enveloped viruses differ from non-enveloped ones in these situations. Enveloped viruses tend to fuse their membrane to release the genome inside the cytoplasm of the host using cytoplasmic endosomes. This way, fusogenic peptides that work in low $\mathrm{pH}$ facilitate access to cytoplasmic endosomes. In response, the release of molecules by the cells can prevent $\mathrm{pH}$ lowering, which inhibits the capability of virion fusion.

Non-enveloped viruses (such as enteroviruses) accumulate in endosomes and present high acidity. Identification of these viruses depends on the receptors exposed on the surface of the cells, to which viruses attach. Enteroviruses usually read $\alpha 2 \beta 1$ integrin, while adenoviruses and coxsackieviruses use coxsackie and adenovirus receptors [132,133]. Viruses with an RNA genome initiate their translation and transcription in the cytoplasm, turning them into specific targets to inhibitors inside the cell. On the other hand, DNA viruses need to penetrate the nucleus to start the process of replication. During translation and transcription, there is an abundance of proteins and viral polymerases, thus creating a target for drugs with inhibitory action. Assembly of non-enveloped viruses generally 
occurs in the cytoplasm, lysing the cell and spreading viral particles to other cells [134]. In addition, replication alters the functions of endosomes, as well as ER and Golgi, required for viral replication $[135,136]$. Even cholesterols and lipidic structures are unusual, making them targets for antiviral drugs $[137,138]$.

Viruses essentially depend on manipulation of apoptosis to successfully replicate. This is necessary for the virus to interrupt anti-apoptotic growth factors in the early stages of replication and boost replication at the end of the cycle, with pro-apoptotic caspases assisting in viral dispersion in the cells. Considering this, some drugs exploit cellular apoptosis activity, which includes, for example, the recognition of viral invasion by pattern recognition receptors (PRRs) and the signaling to Bcl-2 proteins, proteins essential to the apoptosis process by regulation of pro-apoptotic and anti-apoptotic intracellular signals [139-141]. The process initially includes the recognition of viral invasion by pattern recognition receptors (PRRs) and the signaling to Bcl-2 proteins, proteins which are members of the B cell lymphoma 2 (BCL-2) gene family.

The replication of the hepatitis C virus recruits a NS3 protease, which is a serine protease with activity at the amino-terminal and helicase function at the carboxyl-terminal. These two functions elect NS3 as an efficient target for antiviral therapy [142,143].

Paclitaxel is a compound initially isolated from parts of western yew in 1960, and is used as an anticancer drug [144]. Endophytic fungi were identified as feasible alternatives as producers when compared to western yew producers [145]. Fusarium oxysporum endophytic fungi isolated from Rhizophora annamalayana was observed as an example of a paclitaxel producer [146]. Besides having anticancer and antitumor activities, paclitaxel also presents anti-HIV activities, acting in the processes before and after viral invasion. At a concentration of $20 \mu \mathrm{g} / \mathrm{mL}$, paclitaxel from fungi provided a $66 \%$ inhibition efficiency against the HIV-1 pseudo-virus. Although the inhibition effect over HIV-1 integrase has been relatively weak, the inhibition activity against the viral protease was as high as that observed with pepstatin A (a known HIV-1 protease inhibitor), which was enough to hinder the success of viral replication [147].

The Neosartorya udagawae HDN13-313 strain (which metabolome presents the Neosartoryadins A and B secondary metabolites) was found in roots of the mangrove plant Aricennia marina. These fumiquinazoline alkaloids displayed, respectively, $\mathrm{IC}_{50}$ values of 66 and $58 \mu \mathrm{M}$ against the virus H1N1, which is a better result than that observed for the synthetic drug Ribavirin $\left(\mathrm{IC}_{50}=94 \mu \mathrm{M}\right)$ [76]. Other compounds investigated concerning H1N1 antiviral activity were the Emerimidine A and B isodolines and the pestalotiopsone F, pestalotiopsone B, 3,8-dihydroxy-6-methyl-9-oxo-9H-xanthene-1-carboxylate and 5 -chloroisothiorin polyketides. The isodolines and polyketides were isolated from the Emericella sp. fungus of the mangrove plant Aegiceras corniculatum and the Pestalotiopsis spp. fungus of the mangrove plant Rhizophora stylosa [63] (Table 2). These studies demonstrate the value of biocompounds obtained from endophytic fungi as a source of a new, unexplored, bioactive niche of biocontrollers for pathogens such as protozoan, bacteria and viruses.

\section{Future Challenges}

The abundance of natural compounds present in mangrove areas is an example of biocompound richness, given the plethora of unexplored secondary metabolites [148]. Several studies have reported this production of pathogen biocontrollers as a defense mechanism developed to the presence of fungi in plants $[149,150]$. Beyond the natural benefits of exploring this niche, there are other ways to obtain such metabolites. In general, these molecules are produced in low quantities as part of the plant's defense mechanisms. However, some techniques may enhance the production of secondary metabolites, such as strain improvement, one strain-many compounds (OSMAC), epigenetic modulation and conducted stress.

A common technique used for this purpose is co-cultivation. It consists in cultivating microorganisms that are antagonistic or that depend on the same resources, which leads 
to competition. Several of these compounds are not produced in axenic cultivation. Nevertheless, co-cultivation makes it possible to stimulate cryptic compounds, allowing for the discovery of new molecules [151]. Co-cultivation of marine-derived fungi Emericella spp. and actinomycete Salinispora arenicola allowed for the discovery of compound Emericellamides A and B, which presented antibacterial activity [152]. Compounds such as Neoaspergillic acid, Ergosterol and Aspergicin were isolated utilizing co-cultivation of mangrove epiphyte and present antibacterial activity against Gram-positive bacteria [153].

The application of epigenetic elicitors presents a viable niche to be explored, albeit the omics knowledge and genome data are still unclear and require further studies. Beyond that, the knowledge hitherto obtained about evolution, ecology and interaction pattern with plants and other microbes is limited, hampering the discovery process. Another difficulty is the long process of screening strains and obtaining new compounds. In addition, the process of deciphering bioactive compounds from endophytes in lab conditions entails a diminution of metabolite production compared to the yield result of repeated subculturing.

Author Contributions: Conceptualization, R.D.C., I.M.A.d.S.B., M.S., L.P.S., D.R.-L. and G.F.; writingoriginal draft preparation, R.D.C., I.T.S., D.R., A.C.C.d.C., S.A.J. and H.T.; writing-review and editing, D.R.-L., G.F. and J.M.L. All authors have read and agreed to the published version of the manuscript.

Funding: Thanks are extended to Research and Innovation Support Foundation of Santa Catarina State-(grant number PRONEM-2020TR715).

Institutional Review Board Statement: Not applicable.

Informed Consent Statement: Not applicable.

Data Availability Statement: The data presented in this study are available upon request from the corresponding authors.

Acknowledgments: Thanks are extended to GAIN (Axencia Galega de Innovación) for supporting this review (grant number IN607A2019/01).

Conflicts of Interest: The authors declare no conflict of interest.

\section{References}

1. Elshafie, H.S.; Caputo, L.; De Martino, L.; Grul'ová, D.; Zheljazkov, V.V.; De Feo, V.; Camele, I. Biological investigations of essential oils extracted from three Juniperus species and evaluation of their antimicrobial, antioxidant and cytotoxic activities. J. Appl. Micro 2020, 129, 1261-1271. [CrossRef] [PubMed]

2. Camele, I.; Elshafie, H.S.; Caputo, L.; Sakr, S.H.; de Feo, V. Bacillus mojavensis: Biofilm formation and biochemical investigation of its bioactive metabolites. J. Bio. Res. 2019, 92, 39-45. [CrossRef]

3. Cragg, G.M.; Newman, D.J. Biodiversity: A continuing source of novel drug leads*. Pure Appl. Chem. 2005, 77, 26-31. [CrossRef]

4. Strohl, W.R. The role of natural products in a modern drug discovery program. Drug Discov. Today 2000. [CrossRef]

5. Li, J.W.H.; Vederas, J.C. Drug discovery and natural products: End of an era or an endless frontier? Science 2009. [CrossRef]

6. Dias, D.A.; Urban, S.; Roessner, U. A Historical Overview of Natural Products in Drug Discovery. Metabolites 2012, 2, 303-336. [CrossRef]

7. Wang, K.-W.; Wang, S.-W.; Wu, B.; Wei, J.-G. Bioactive Natural Compounds from the Mangrove Endophytic Fungi. Mini Rev. Med. Chem. 2014, 14, 370-391. [CrossRef] [PubMed]

8. Gupta, S.; Chaturvedi, P.; Kulkarni, M.G.; Van Staden, J. A critical review on exploiting the pharmaceutical potential of plant endophytic fungi. Biotechnol. Adv. 2020, 39, 107462. [CrossRef] [PubMed]

9. Jakubczyk, D.; Dussart, F. Selected Fungal Natural Products with Antimicrobial Properties. Molecules 2020, 25, 911. [CrossRef] [PubMed]

10. Elshafie, H.S.; Camele, I. An Overview of Metabolic Activity, Beneficial and Pathogenic Aspects of Burkholderia spp. Metabolites 2021, 11, 321. [CrossRef]

11. Fleming, A. On the antibacterial action of cultures of a penicillium, with special reference to their use in the isolation of $b$. influenz? Br. J. Exp. Pathol. 1929, 10, 226-236. [CrossRef]

12. Amit Koparde, A.; Chandrashekar Doijad, R.; Shripal Magdum, C. Natural Products in Drug Discovery. In PharmacognosyMedicinal Plants; IntechOpen: London, UK, 2019. [CrossRef]

13. Ancheeva, E.; El-Neketi, M.; Daletos, G.; Ebrahim, W.; Song, W.; Lin, W.; Proksch, P. Anti-infective Compounds from Marine Organisms. Grand Chall. Mar. Biotechnol. 2018, 97-155. [CrossRef]

14. Rafferty, J.P. Lakes and Wetlands South America. 2011. Available online: https://books.google.com.br/books?id=StCGBdKR4qgC\& printsec $=$ frontcover\&hl=pt-BR\&source=gbs_ge_summary_r\&cad=0\#v=onepage\&q\&f=false (accessed on 14 September 2020). 
15. Francisco, P.M.; Tambarussi, E.V.; de Alves, F.M.; Bajay, S.; Ciampi-Guillardi, M.; Souza, A.P. Genetic diversity and mating system of rhizophora mangle 1. (rhizophoraceae) in Northern Brazil revealed by microsatellite analysis. Cerne 2018, 24, 295-302. [CrossRef]

16. Silva, J.M.; Martins, M.B.G.; Cavalheiro, A.J. Caracterização anatômica e perfis químicos de folhas de Avicennia schaueriana Stapf. \& Leech. ex Moldenke e Rhizophora mangle L. de manguezais impactados e não impactados do litoral paulista. Insul. Rev. Botânica 2010, 39, 14-33. [CrossRef]

17. Glauce Brasil, A. A efetividade da gestão das unidades de conservação na proteção dos sistemas de manguezais na ilha de santa Catarina. Doctoral Thesis, Universidade Federal de Santa Catarina, Florianópolis, Brazil, 2017.

18. Patra, J.K.; Thatoi, H.N. Metabolic diversity and bioactivity screening of mangrove plants: A review. Acta Physiol. Plant. 2011. [CrossRef]

19. Rajpar, M.N.; Zakaria, M. Mangrove fauna of Asia. In Mangrove Ecosystems of Asia; Springer: New York, NY, USA, 2014; pp. 153-197. [CrossRef]

20. Cribb, J.W. WoRMS-World Register of Marine Species-Lulworthia cylindrica (Linder) Cribb \& J.W. Cribb, 1955. Available online: http:/ / www.marinespecies.org/aphia.php?p=taxdetails\&id=438136 (accessed on 22 December 2020).

21. Zhou, J.; Diao, X.; Wang, T.; Chen, G.; Lin, Q.; Yang, X.; Xu, J. Phylogenetic diversity and antioxidant activities of culturable fungal endophytes associated with the mangrove species Rhizophora stylosa and R. mucronata in the South China Sea. PLoS ONE 2018, 13, e0197359. [CrossRef] [PubMed]

22. Sun, X.; Guo, L.D. Endophytic fungal diversity: Review of traditional and molecular techniques. Mycology 2012, 3, 65-76. [CrossRef]

23. Rajesh, R.W.; Rahul, M.S.; Ambalal, N.S. Trichoderma: A significant fungus for agriculture and environment. Afr. J. Agric. Res. 2016, 11, 1952-1965. [CrossRef]

24. Adnan, M.; Islam, W.; Shabbir, A.; Khan, K.A.; Ghramh, H.A.; Huang, Z.; Chen, H.Y.H.; Lu, G.-G. Plant defense against fungal pathogens by antagonistic fungi with Trichoderma in focus. Microb. Pathog. 2019. [CrossRef]

25. Luo, J.M.; Xiao, X.; Luo, S.L. Biosorption of cadmium(II) from aqueous solutions by industrial fungus Rhizopus cohnii. Trans. Nonferrous Met. Soc. China 2010, 20, 1104-1111. [CrossRef]

26. Petruzzello, M. Rhizopus I Fungus Genus | Britannica. Encycl. Br. 2016. Available online: https://www.britannica.com/science/ Rhizopus (accessed on 22 December 2020).

27. Biasetto, C.R.; Somensi, A.; Figueiro, F.S.; De Moraes, L.A.B.; Silva, G.H.; Marx Young, M.C.; Da Silva Bolzani, V.; Araújo, A.R. Diketopiperazines and arylethylamides produced by Schizophyllum commune, an endophytic fungus in Alchornea glandulosa. Eclet. Quim. 2019, 44, 36-42. [CrossRef]

28. Costa, I.P.M.W.; Maia, L.C.; Cavalcanti, M.A. Diversity of leaf endophytic fungi in mangrove plants of Northeast Brazil. Braz. J. Microbiol. 2012, 43, 1165-1173. [CrossRef]

29. De Souza Sebastianes, F.L.; Romão-Dumaresq, A.S.; Lacava, P.T.; Harakava, R.; Azevedo, J.L.; De Melo, I.S.; Pizzirani-Kleiner, A.A. Species diversity of culturable endophytic fungi from Brazilian mangrove forests. Curr. Genet. 2013, 59, 153-166. [CrossRef] [PubMed]

30. Taub, L. Universidade Federal de Alfenas Rayra Annara da Fonseca Otacílio Pinto Bioprospecção e Caracterização de Fungos Endofíticos Produtores de Compostos Bioativos Isolados de Dalbergia; Universidade Federal de Alfenas: Alfenas, Brazil, 2019.

31. Rajamanikyam, M.; Vadlapudi, V.; Amanchy, R.; Upadhyayula, S.M. Endophytic fungi as novel resources of natural therapeutics. Braz. Arch. Biol. Technol. 2017, 60, 17160542. [CrossRef]

32. Hammerschmidt, L.; Debbab, A.; Ngoc, T.D.; Wray, V.; Hemphil, C.P.; Lin, W.; Broetz-Oesterhelt, H.; Kassack, M.U.; Proksch, P.; Aly, A.H. Polyketides from the mangrove-derived endophytic fungus Acremonium strictum. Tetrahedron Lett. 2014, 55, 3463-3468. [CrossRef]

33. Rukachaisirikul, V.; Rodglin, A.; Sukpondma, Y.; Phongpaichit, S.; Buatong, J.; Sakayaroj, J. Phthalide and Isocoumarin Derivatives Produced by an Acremonium sp. Isolated from a Mangrove Rhizophora apiculata. J. Nat. Prod. 2012. [CrossRef]

34. Ranganathan, N.; Mahalingam, G. Secondary metabolite as therapeutic agent from endophytic fungi Alternaria longipes strain VITN14G of mangrove plant Avicennia officinalis. J. Cell. Biochem. 2019, 120, 4021-4031. [CrossRef] [PubMed]

35. Wang, J.; Ding, W.; Wang, R.; Du, Y.; Liu, H.; Kong, X.; Li, C. Identification and bioactivity of compounds from the mangrove endophytic fungus Alternaria sp. Mar. Drugs 2015, 13, 4492-4504. [CrossRef]

36. Hamzah, T.N.T.; Lee, S.Y.; Hidayat, A.; Terhem, R.; Faridah-Hanum, I.; Mohamed, R. Diversity and characterization of endophytic fungi isolated from the tropical mangrove species, Rhizophora mucronata, and identification of potential antagonists against the soil-borne fungus, Fusarium solani. Front. Microbiol. 2018, 9, 1707. [CrossRef]

37. Chen, Y.; Liu, Z.; Liu, H.; Pan, Y.; Li, J.; Liu, L.; She, Z. Dichloroisocoumarins with Potential Anti-Inflammatory Activity from the Mangrove Endophytic Fungus Ascomycota sp. CYSK-4. Mar. Drugs 2018, 16, 54. [CrossRef]

38. Li, W.; Xiong, P.; Zheng, W.; Zhu, X.; She, Z.; Ding, W.; Li, C. Identification and Antifungal Activity of Compounds from the Mangrove Endophytic Fungus Aspergillus clavatus R7. Mar. Drugs 2017, 15, 259. [CrossRef]

39. Bai, Z.Q.; Wang, Y.; Lin, X.; Wang, Y.; Wang, J.; Zhou, X.; Yang, B.; Liu, J.; Yang, X.; Liu, Y. New phenyl derivatives from endophytic fungus Aspergillus flavipes AIL8 derived of mangrove plant Acanthus ilicifolius. Fitoterapia 2014, 95, 194-202. [CrossRef] [PubMed] 
40. Wang, H.; Lu, Z.; Qu, H.J.; Liu, P.; Miao, C.; Zhu, T.; Li, J.; Hong, K.; Zhu, W. Antimicrobial aflatoxins from the marine-derived fungus Aspergillus flavus 092008. Arch. Pharm. Res. 2012, 35, 1387-1392. [CrossRef]

41. Handayani, D.; Rivai, H.; Hutabarat, M.; Rasyid, R. Antibacterial activity of endophytic fungi isolated from mangrove plant Sonneratia griffithii Kurz. J. Appl. Pharm. Sci. 2017, 7, 209-212. [CrossRef]

42. Wu, Y.; Chen, Y.; Huang, X.; Pan, Y.; Liu, Z.; Yan, T.; Cao, W.; She, Z. $\alpha$-Glucosidase Inhibitors: Diphenyl Ethers and Phenolic Bisabolane Sesquiterpenoids from the Mangrove Endophytic Fungus Aspergillus flavus QQSG-3. Mar. Drugs 2018, 16, 307. [CrossRef]

43. Guo, Z.; Gai, C.; Cai, C.; Chen, L.; Liu, S.; Zeng, Y.; Yuan, J.; Mei, W.; Dai, H. Metabolites with Insecticidal Activity from Aspergillus fumigatus JRJ111048 Isolated from Mangrove Plant Acrostichum specioum Endemic to Hainan Island. Mar. Drugs 2017, 15, 381. [CrossRef] [PubMed]

44. An, C.Y.; Li, X.M.; Luo, H.; Li, C.S.; Wang, M.H.; Xu, G.M.; Wang, B.G. 4-Phenyl-3,4-dihydroquinolone derivatives from aspergillus nidulans MA-143, an endophytic fungus isolated from the mangrove plant rhizophora stylosa. J. Nat. Prod. 2013, 76, 1896-1901. [CrossRef] [PubMed]

45. Yang, S.Q.; Li, X.M.; Xu, G.M.; Li, X.; An, C.Y.; Wang, B.G. Antibacterial anthraquinone derivatives isolated from a mangrovederived endophytic fungus Aspergillus nidulans by ethanol stress strategy. J. Antibiot. 2018, 71, 778-784. [CrossRef]

46. Liu, D.; Li, X.M.; Li, C.S.; Wang, B.G. Nigerasterols A and B, antiproliferative sterols from the mangrove-derived endophytic fungus Aspergillus niger MA-132. Helv. Chim. Acta 2013, 96, 1055-1061. [CrossRef]

47. Nurunnabi, T.R.; Sabrin, F.; Sharif, D.I.; Nahar, L.; Sohrab, M.H.; Sarker, S.D.; Rahman, S.M.M.; Billah, M.M. Antimicrobial activity of endophytic fungi isolated from the mangrove plant Sonneratia apetala (Buch.-Ham) from the Sundarbans mangrove forest. Adv. Tradit. Med. 2020, 20, 419-425. [CrossRef]

48. Nurunnabi, T.R.; Nahar, L.; Al-Majmaie, S.; Rahman, S.M.M.; Sohrab, M.H.; Billah, M.M.; Ismail, F.M.D.; Rahman, M.M.; Sharples, G.P.; Sarker, S.D. Anti-MRSA activity of oxysporone and xylitol from the endophytic fungus Pestalotia sp. growing on the Sundarbans mangrove plant Heritiera fomes. Phyther. Res. 2018, 32, 348-354. [CrossRef]

49. Li, S.; Wei, M.; Chen, G.; Lin, Y. Two new dihydroisocoumarins from the endophytic fungus Aspergillus sp. Collected from the South China Sea. Chem. Nat. Compd. 2012, 48, 371-373. [CrossRef]

50. Akinduyite, A.E.; Ariole, C.N. Bioactive compounds and antibacterial activity of endophytic fungi isolated from Black Mangrove (Avicennia africana) leaves. Niger. J. Biotechnol. 2019, 35, 35. [CrossRef]

51. Wang, L.; Han, X.; Zhu, G.; Wang, Y.; Chairoungdua, A.; Piyachaturawat, P.; Zhu, W. Polyketides from the Endophytic Fungus Cladosporium sp. Isolated From the Mangrove Plant Excoecaria agallocha. Front. Chem. 2018, 6, 344. [CrossRef]

52. Wu, Y.; Chen, S.; Liu, H.; Huang, X.; Liu, Y.; Tao, Y.; She, Z. Cytotoxic isocoumarin derivatives from the mangrove endophytic fungus Aspergillus sp. HN15-5D. Arch. Pharm. Res. 2019, 42, 326-331. [CrossRef]

53. Cai, R.; Jiang, H.; Zang, Z.; Li, C.; She, Z. New Benzofuranoids and Phenylpropanoids from the Mangrove Endophytic Fungus, Aspergillus sp. ZJ-68. Mar. Drugs 2019, 17, 478. [CrossRef] [PubMed]

54. Huang, H.B.; Feng, X.J.; Liu, L.; Chen, B.; Lu, Y.J.; Ma, L.; She, Z.G.; Lin, Y.C. Three dimeric naphtho- $\gamma$-pyrones from the mangrove endophytic fungus Aspergillus tubingensis isolated from Pongamia pinnata. Planta Med. 2010, 76, 1888-1891. [CrossRef] [PubMed]

55. Cui, H.; Liu, Y.; Ding, M.; Zhang, Z.; Liu, H.; Huang, X.; She, Z. New pyranonaphthazarin and 2-naphthoic acid derivatives from the mangrove endophytic fungus Leptosphaerulina sp. SKS032. Phytochem. Lett. 2017, 20, 214-217. [CrossRef]

56. Zhu, M.; Zhang, X.; Feng, H.; Che, Q.; Zhu, T.; Gu, Q.; Li, D. Campyridones A-D, pyridone alkaloids from a mangrove endophytic fungus Campylocarpon sp. HDN13-307. Tetrahedron 2016, 72, 5679-5683. [CrossRef]

57. Chaeprasert, S.; Piapukiew, J.; Whalley, A.J.S.; Sihanonth, P. Endophytic fungi from mangrove plant species of Thailand: Their antimicrobial and anticancer potentials. Bot. Mar. 2010, 53, 555-564. [CrossRef]

58. Ai, W.; Lin, X.; Wang, Z.; Lu, X.; Mangaladoss, F.; Yang, X.; Zhou, X.; Tu, Z.; Liu, Y. Cladosporone A, a new dimeric tetralone from fungus Cladosporium sp. KcFL6' derived of mangrove plant Kandelia candel. J. Antibiot. 2015, 68, 213-215. [CrossRef]

59. Bin, G.; Chen, Y.; Zhang, H.; Zheng, X.; Zhang, Y.; Fang, H.; Zhong, Q.; Chenxiao, Z. Isolation, characterization and anti-multiple drug resistant (MDR) bacterial activity of endophytic fungi isolated from the mangrove plant, Aegiceras corniculatum. Trop. J. Pharm. Res. 2014, 13, 593-599. [CrossRef]

60. Luo, X.W.; Chen, C.M.; Li, K.L.; Lin, X.P.; Gao, C.H.; Zhou, X.F.; Liu, Y.H. Sesquiterpenoids and meroterpenoids from a mangrove derived fungus Diaporthe sp. SCSIO 41011. Nat. Prod. Res. 2019, 1-7. [CrossRef] [PubMed]

61. Wei, C.; Deng, Q.; Sun, M.; Xu, J. Cytospyrone and Cytospomarin: Two new polyketides isolated from mangrove endophytic fungus, Cytospora sp ${ }^{\dagger}$. Molecules 2020, 25, 4224. [CrossRef] [PubMed]

62. Liao, H.X.; Shao, T.M.; Mei, R.Q.; Huang, G.L.; Zhou, X.M.; Zheng, C.J.; Wang, C.Y. Bioactive Secondary Metabolites from the Culture of the Mangrove-Derived Fungus Daldinia eschscholtzii HJ004. Mar. Drugs 2019, 17, 710. [CrossRef] [PubMed]

63. Luo, X.; Yang, J.; Chen, F.; Lin, X.; Chen, C.; Zhou, X.; Liu, S.; Liu, Y. Structurally diverse polyketides from the mangrove-derived fungus diaporthe sp. SCSIO 41011 with their anti-influenza A virus activities. Front. Chem. 2018, 6, 282. [CrossRef]

64. Du, X.P.; Su, W.J. Two new polyketides from mangrove endophytic fungus dothiorella sp. Chem. Nat. Compd. 2014, 50, 214-216. [CrossRef]

65. Zhang, G.; Sun, S.; Zhu, T.; Lin, Z.; Gu, J.; Li, D.; Gu, Q. Antiviral isoindolone derivatives from an endophytic fungus Emericella sp. associated with Aegiceras corniculatum. Phytochemistry 2011, 72, 1436-1442. [CrossRef] [PubMed] 
66. Mei, R.Q.; Nong, X.H.; Wang, B.; Sun, X.P.; Huang, G.L.; Luo, Y.P.; Zheng, C.J.; Chen, G.Y. A new phenol derivative isolated from mangrove-derived fungus Eupenicillium sp. HJ002. Nat. Prod. Res. 2020. [CrossRef] [PubMed]

67. May Zin, W.W.; Buttachon, S.; Dethoup, T.; Pereira, J.A.; Gales, L.; Inácio, Â.; Costa, P.M.; Lee, M.; Sekeroglu, N.; Silva, A.M.S.; et al. Antibacterial and antibiofilm activities of the metabolites isolated from the culture of the mangrove-derived endophytic fungus Eurotium chevalieri KUFA 0006. Phytochemistry 2017, 141, 86-97. [CrossRef]

68. Yan, H.J.; Li, X.M.; Li, C.S.; Wang, B.G. Alkaloid and anthraquinone derivatives produced by the marine-derived endophytic fungus Eurotium rubrum. Helv. Chim. Acta 2012, 95, 163-168. [CrossRef]

69. Supratman, U.; Hirai, N.; Sato, S.; Watanabe, K.; Malik, A.; Annas, S.; Harneti, D.; Maharani, R.; Koseki, T.; Shiono, Y. New naphthoquinone derivatives from Fusarium napiforme of a mangrove plant. Nat. Prod. Res. 2019, 1-7. [CrossRef] [PubMed]

70. Ling, O.M.; Teen, L.P.; Mujahid, A.; Proksch, P.; Müller, M. Initial screening of mangrove endophytic fungi for antimicrobial compounds and heavy metal biosorption potential. Sains Malays. 2016, 45, 1063-1071.

71. Mei, W.L.; Zheng, B.; Zhao, Y.X.; Zhong, H.M.; Chen, X.L.W.; Zeng, Y.B.; Dong, W.H.; Huang, J.L.; Proksch, P.; Dai, H.F. Meroterpenes from endophytic fungus A1 of mangrove plant Scyphiphora hydrophyllacea. Mar. Drugs 2012, 10, 1993-2001. [CrossRef] [PubMed]

72. Chi, W.C.; Pang, K.L.; Chen, W.L.; Wang, G.J.; Lee, T.H. Antimicrobial and iNOS inhibitory activities of the endophytic fungi isolated from the mangrove plant Acanthus ilicifolius var. xiamenensis. Bot. Stud. 2019, 60, 4. [CrossRef] [PubMed]

73. Ratnaweera, P.B.; De Silva, E.D.; Wijesundera, R.L.; Andersen, R.J. Antimicrobial constituents of Hypocrea virens, an endophyte of the mangrove-associate plant Premna serratifolia L. J. Natl. Sci. Found. Sri Lanka 2016, 44, 43. [CrossRef]

74. Chen, S.; Liu, Z.; Liu, H.; Long, Y.; Chen, D.; Lu, Y.; She, Z. Lasiodiplactone A, a novel lactone from the mangrove endophytic fungus Lasiodiplodia theobromae ZJ-HQ1. Org. Biomol. Chem. 2017, 15, 6338-6341. [CrossRef] [PubMed]

75. Mazlan, N.W.; Tate, R.; Yusoff, Y.M.; Clements, C.; Edrada-Ebel, R. Metabolomics-Guided Isolation of Anti-Trypanosomal Compounds from Endophytic Fungi of the Mangrove plant Avicennia Lanata. Curr. Med. Chem. 2019, 27, 1815-1835. [CrossRef]

76. Cui, H.; Liu, Y.; Li, T.; Zhang, Z.; Ding, M.; Long, Y.; She, Z. 3-Arylisoindolinone and sesquiterpene derivatives from the mangrove endophytic fungi Aspergillus versicolor SYSU-SKS025. Fitoterapia 2018, 124, 177-181. [CrossRef]

77. Yu, G.; Zhou, G.; Zhu, M.; Wang, W.; Zhu, T.; Gu, Q.; Li, D. Neosartoryadins A and B, Fumiquinazoline Alkaloids from a Mangrove-Derived Fungus Neosartorya udagawae HDN13-313. Org. Lett. 2015. [CrossRef]

78. Xia, X.; Li, Q.; Li, J.; Shao, C.; Zhang, J.; Zhang, Y.; Liu, X.; Lin, Y.; Liu, C.; She, Z. Two new derivatives of griseofulvin from the mangrove endophytic fungus nigrospora sp(Strain No.1403) from Kandelia candel (L.) Druce. Planta Med. 2011, 77, 1735-1738. [CrossRef]

79. Ukwatta, K.M.; Lawrence, J.L.; Wijayarathna, C.D. The study of antimicrobial, anti-cancer, anti-inflammatory and $\alpha$-glucosidase inhibitory activities of Nigronapthaphenyl, isolated from an extract of Nigrospora sphaerica. Mycol. Int. J. Fungal Biol. 2019. [CrossRef] [PubMed]

80. Meng, L.H.; Zhang, P.; Li, X.M.; Wang, B.G. Penicibrocazines A-E, five new sulfide diketopiperazines from the marine-derived endophytic fungus Penicillium brocae. Mar. Drugs 2015, 13, 276-287. [CrossRef]

81. Meng, L.H.; Li, X.M.; Liu, Y.; Xu, G.M.; Wang, B.G. Antimicrobial alkaloids produced by the mangrove endophyte Penicillium brocae MA-231 using the OSMAC approach. RSC Adv. 2017, 7, 55026-55033. [CrossRef]

82. Devi, P.; Rodrigues, C.; Naik, C.G.; D'Souza, L. Isolation and Characterization of Antibacterial Compound from a MangroveEndophytic Fungus, Penicillium chrysogenum MTCC 5108. Indian J. Microbiol. 2012, 52, 617-623. [CrossRef] [PubMed]

83. Zhu, X.; Wu, Z.; Liang, F.; Gan, S.; Huang, Q.; Ding, W.; Li, C. A New L-alanine Derivative from the Mangrove Fungus Penicillium chrysogenum V11. Chem. Nat. Compd. 2018, 54, 520-522. [CrossRef]

84. Huang, S.; Xu, J.; Li, F.; Zhou, D.; Xu, L.; Li, C. Identification and Antifungal Activity of Metabolites from the Mangrove Fungus Phoma sp. L28. Chem. Nat. Compd. 2017, 53, 237-240. [CrossRef]

85. He, K.Y.; Zhang, C.; Duan, Y.R.; Huang, G.L.; Yang, C.Y.; Lu, X.R.; Zheng, C.J.; Chen, G.Y. New chlorinated xanthone and anthraquinone produced by a mangrove-derived fungus Penicillium citrinum HL-5126. J. Antibiot. 2017, 70, 823-827. [CrossRef] [PubMed]

86. Cao, J.; Li, X.M.; Li, X.; Li, H.L.; Meng, L.H.; Wang, B.G. New lactone and isocoumarin derivatives from the marine mangrovederived endophytic fungus Penicillium coffeae MA-314. Phytochem. Lett. 2019, 32, 1-5. [CrossRef]

87. Hayibor, K.; Kwain, S.; Osei, E.; Nartey, A.P.; Tetevi, G.M.; Owusu, K.B.-A.; Camas, M.; Camas, A.S.; Kyeremeh, K. Ghanaian mangrove wetland endophytic fungus, Penicillium herquei strain BRS2A-AR produces (9Z, 11E)-13-oxooctadeca-9,11-dienoic acid with activity against Trichomonas mobilensis. Int. J. Biol. Chem. Sci. 2019, 13, 1918. [CrossRef]

88. Xu, R.; Li, X.M.; Wang, B.G. Penicisimpins A-C, three new dihydroisocoumarins from Penicillium simplicissimum MA-332, a marine fungus derived from the rhizosphere of the mangrove plant Bruguiera sexangula var. rhynchopetala. Phytochem. Lett. 2016, 17, 114-118. [CrossRef]

89. Zheng, C.; Chen, Y.; Jiang, L.L.; Shi, X.M. Antiproliferative metabolites from the endophytic fungus Penicillium sp. FJ-1 isolated from a mangrove Avicennia marina. Phytochem. Lett. 2014, 10, 272-275. [CrossRef]

90. Ding, B.; Wang, Z.; Huang, X.; Liu, Y.; Chen, W.; She, Z. Bioactive $\alpha$-pyrone meroterpenoids from mangrove endophytic fungus Penicillium sp. Nat. Prod. Res. 2016, 30, 2805-2812. [CrossRef]

91. Qi, X.; Li, X.; Zhao, J.; He, N.; Li, Y.; Zhang, T.; Wang, S.; Yu, L.; Xie, Y. GKK1032C, a new alkaloid compound from the endophytic fungus Penicillium sp. CPCC 400817 with activity against methicillin-resistant S. aureus. J. Antibiot. 2019, 72, 237-240. [CrossRef] 
92. Hemberger, Y.; Xu, J.; Wray, V.; Proksch, P.; Wu, J.; Bringmann, G. Pestalotiopens A and B: Stereochemically Challenging Flexible Sesquiterpene-Cyclopaldic Acid Hybrids from Pestalotiopsis sp. Chem. A Eur. J. 2013, 19, 15556-15564. [CrossRef] [PubMed]

93. Xu, Z.; Xiong, B.; Xu, J. Chemical Investigation of Secondary Metabolites Produced by Mangrove Endophytic Fungus Phyllosticta Capitalensis. Nat. Prod. Res. 2019. [CrossRef]

94. Xu, Z.; Wu, X.; Li, G.; Feng, Z.; Xu, J. Pestalotiopisorin B, a new isocoumarin derivative from the mangrove endophytic fungus Pestalotiopsis sp. HHL101. Nat. Prod. Res. 2020, 34, 1002-1007. [CrossRef]

95. Huang, G.L.; Zhou, X.M.; Bai, M.; Liu, Y.X.; Zhao, Y.L.; Luo, Y.P.; Niu, Y.Y.; Zheng, C.J.; Chen, G.Y. Dihydroisocoumarins from the mangrove-derived fungus Penicillium citrinum. Mar. Drugs 2016, 14, 177. [CrossRef] [PubMed]

96. Klaiklay, S.; Rukachaisirikul, V.; Phongpaichit, S.; Pakawatchai, C.; Saithong, S.; Buatong, J.; Preedanon, S.; Sakayaroj, J. Anthraquinone derivatives from the mangrove-derived fungus Phomopsis sp. PSU-MA214. Phytochem. Lett. 2012, 5, 738-742. [CrossRef]

97. Zhang, D.; Tao, X.; Chen, R.; Liu, J.; Li, L.; Fang, X.; Yu, L.; Dai, J. Pericoannosin A, a Polyketide Synthase-Nonribosomal Peptide Synthetase Hybrid Metabolite with New Carbon Skeleton from the Endophytic Fungus Periconia sp. Org. Lett. 2015, 17, $4304-4307$. [CrossRef] [PubMed]

98. Cai, R.; Chen, S.; Liu, Z.; Tan, C.; Huang, X.; She, Z. A new $\alpha$-pyrone from the mangrove endophytic fungus Phomopsis sp. HNY29-2B. Nat. Prod. Res. 2017, 2, 124-130. [CrossRef]

99. Wen, S.; Fan, W.; Guo, H.; Huang, C.; Yan, Z.; Long, Y. Two new secondary metabolites from the mangrove endophytic fungus Pleosporales sp. SK7. Nat. Prod. Res. 2019. [CrossRef]

100. Joel, E.L.; Bhimba, B.V. A secondary metabolite with antibacterial activity produced by mangrove foliar fungus Schizophyllum commune. Int. J. Chem. Env. Biol. Scn. 2013, 1, 2320-4087.

101. Zhou, X.M.; Zheng, C.J.; Chen, G.Y.; Song, X.P.; Han, C.R.; Li, G.N.; Fu, Y.H.; Chen, W.H.; Niu, Z.G. Bioactive anthraquinone derivatives from the mangrove-derived fungus stemphylium sp. 33231. J. Nat. Prod. 2014, 77, 2021-2028. [CrossRef]

102. Liu, F.; Cai, X.L.; Yang, H.; Xia, X.K.; Guo, Z.Y.; Yuan, J.; Li, M.F.; She, Z.G.; Lin, Y.C. The bioactive metabolites of the mangrove endophytic fungus talaromyces sp. ZH-154 isolated from kandelia candel (L.) Druce. Planta Med. 2010, 76, 185-189. [CrossRef] [PubMed]

103. Zhang, L.; Niaz, S.I.; Wang, Z.; Zhu, Y.; Lin, Y.; Li, J.; Liu, L. $\alpha$-Glucosidase inhibitory and cytotoxic botryorhodines from mangrove endophytic fungus Trichoderma sp. 307. Nat. Prod. Res. 2018, 32, 2887-2892. [CrossRef]

104. Arora, D.; Sharma, N.; Singamaneni, V.; Sharma, V.; Kushwaha, M.; Abrol, V.; Guru, S.; Sharma, S.; Gupta, A.P.; Bhushan, S.; et al. Isolation and characterization of bioactive metabolites from Xylaria psidii, an endophytic fungus of the medicinal plant Aegle marmelos and their role in mitochondrial dependent apoptosis against pancreatic cancer cells. Phytomedicine 2016, 23, 1312-1320. [CrossRef] [PubMed]

105. Lopéz, D.; Cherigo, L.; Mejia, L.C.; Loza-Mejía, M.A.; Martínez-Luis, S. $\alpha$-Glucosidase inhibitors from a mangrove associated fungus, Zasmidium sp. strain EM5-10. BMC Chem. 2019, 13, 22. [CrossRef] [PubMed]

106. Strobel, G.; Daisy, B. Bioprospecting for Microbial Endophytes and Their Natural Products. Microbiol. Mol. Biol. Rev. 2003, 67, 491-502. [CrossRef]

107. Saad, M.M.G.; Ghareeb, R.Y.; Saeed, A.A. The potential of endophytic fungi as bio-control agents against the cotton leafworm, Spodoptera littoralis (Boisd.) (Lepidoptera: Noctuidae). Egypt. J. Biol. Pest Control 2019, 29, 7. [CrossRef]

108. Challis, G.L. Mining microbial genomes for new natural products and biosynthetic pathways. Microbiology 2008, 154, 1555-1569. [CrossRef] [PubMed]

109. Cichewicz, R.H. Epigenome manipulation as a pathway to new natural product scaffolds and their congeners. Nat. Prod. Rep. 2010, 27, 11-22. [CrossRef] [PubMed]

110. Chiang, Y.M.; Chang, S.L.; Oakley, B.R.; Wang, C.C.C. Recent advances in awakening silent biosynthetic gene clusters and linking orphan clusters to natural products in microorganisms. Curr. Opin. Chem. Biol. 2011. [CrossRef] [PubMed]

111. Beau, J.; Mahid, N.; Burda, W.N.; Harrington, L.; Shaw, L.N.; Mutka, T.; Kyle, D.E.; Barisic, B.; van Olphen, A.; Baker, B.J. Epigenetic Tailoring for the Production of Anti-Infective Cytosporones from the Marine Fungus Leucostoma persoonii. Mar. Drugs 2012, 10, 762-774. [CrossRef]

112. Lim, F.Y.; Sanchez, J.F.; Wang, C.C.C.; Keller, N.P. Toward awakening cryptic secondary metabolite gene clusters in filamentous fungi. In Methods in Enzymology; Academic Press Inc.: Cambridge, MA, USA, 2012; pp. 303-324. [CrossRef]

113. González-Menéndez, V.; Pérez-Bonilla, M.; Pérez-Victoria, I.; Martín, J.; Muñoz, F.; Reyes, F.; Tormo, J.; Genilloud, O. Multicomponent Analysis of the Differential Induction of Secondary Metabolite Profiles in Fungal Endophytes. Molecules 2016, 21, 234. [CrossRef]

114. Demers, D.; Knestrick, M.; Fleeman, R.; Tawfik, R.; Azhari, A.; Souza, A.; Vesely, B.; Netherton, M.; Gupta, R.; Colon, B.; et al. Exploitation of Mangrove Endophytic Fungi for Infectious Disease Drug Discovery. Mar. Drugs 2018, 16, 376. [CrossRef] [PubMed]

115. Zhang, F.Z.; Li, X.M.; Li, X.; Yang, S.Q.; Meng, L.H.; Wang, B.G. Polyketides from the mangrove-derived endophytic fungus Cladosporium cladosporioides. Mar. Drugs 2019, 17, 296. [CrossRef]

116. World Health Organization. The World Malaria Report 2018; World Health Organization: Geneva, Switzerland, 2018.

117. Shang, Z.; Li, X.-M.; Li, C.-S.; Wang, B.-G. Diverse Secondary Metabolites Produced by Marine-Derived Fungus Nigrospora sp. MA75 on Various Culture Media. Chem. Biodivers. 2012, 9, 1338-1348. [CrossRef] 
118. Wang, J.; Wei, X.; Lu, X.; Xu, F.; Wan, J.; Lin, X.; Zhou, X.; Liao, S.; Yang, B.; Tu, Z.; et al. Eight new polyketide metabolites from the fungus Pestalotiopsis vaccinii endogenous with the mangrove plant Kandelia candel (L.) Druce. Tetrahedron 2014, 70, 9695-9701. [CrossRef]

119. Campos, F.F.; Sales Junior, P.A.; Romanha, A.J.; Araújo, M.S.S.; Siqueira, E.P.; Resende, J.M.; Alves, T.M.A.; Martins-Filho, O.A.; Dos Santos, V.L.; Rosa, C.A.; et al. Bioactive endophytic fungi isolated from caesalpinia echinata Lam. (Brazilwood) and identification of beauvericin as a trypanocidal metabolite from fusarium sp. Mem. Inst. Oswaldo Cruz 2015, 110, 1-10. [CrossRef]

120. Ferreira, M.C.; Vieira M de, L.A.; Zani, C.L.; Alves TM de, A.; Junior, P.A.S.; Murta, S.M.F.; Romanha, A.J.; Gil, L.H.V.G.; Carvalho AG de, O.; Zilli, J.E.; et al. Molecular phylogeny, diversity, symbiosis and discover of bioactive compounds of endophytic fungi associated with the medicinal Amazonian plant Carapa guianensis Aublet (Meliaceae). Biochem. Syst. Ecol. 2015, 59, 36-44. [CrossRef]

121. Rosa, L.H.; Gonçalves, V.N.; Caligiorne, R.B.; Alves, T.M.A.; Rabello, A.; Sales, P.A.; Romanha, A.J.; Sobral, M.E.G.; Rosa, C.A.; Zani, C.L. Leishmanicidal, trypanocidal, and cytotoxic activities of endophytic fungi associated with bioactive plants in Brazil. Braz. J. Microbiol. 2010, 41, 420-430. [CrossRef]

122. De Carvalho, C.R.; De Lourdes Almeida Vieira, M.; Cantrell, C.L.; Wedge, D.E.; Alves, T.M.A.; Zani, C.L.; Pimenta, R.S.; Sales, P.A.; Murta, S.M.F.; Romanha, A.J.; et al. Biological activities of ophiobolin K and 6-epi-ophiobolin K produced by the endophytic fungus Aspergillus calidoustus. Nat. Prod. Res. 2016, 30, 478-481. [CrossRef] [PubMed]

123. Wang, A.; Yin, R.; Zhou, Z.; Gu, G.; Dai, J.; Lai, D.; Zhou, L. Eremophilane-Type Sesquiterpenoids From the Endophytic Fungus Rhizopycnis vagum and Their Antibacterial, Cytotoxic, and Phytotoxic Activities. Front. Chem. 2020, 8, 596889. [CrossRef]

124. Mansoldo, F.R.P.; Carta, F.; Angeli, A.; Cardoso V da, S.; Supuran, C.T.; Vermelho, A.B. Chagas Disease: Perspectives on the Past and Present and Challenges in Drug Discovery. Molecules 2020, 25, 5483. [CrossRef]

125. Newell, D.G.; Koopmans, M.; Verhoef, L.; Duizer, E.; Aidara-Kane, A.; Sprong, H.; Opsteegh, M.; Langelaar, M.; Threfall, J.; Scheutz, F.; et al. Food-borne diseases-The challenges of 20years ago still persist while new ones continue to emerge. Int. J. Food Microbiol. 2010, 139, S3-S15. [CrossRef]

126. Li, H.-Y.; Zhu, G.-J.; Zhang, Y.-Z.; Zhang, L.-B.; Hagan, E.A.; Martinez, S.; Chmura, A.A.; Francisco, L.; Tai, H.; Miller, M.; et al. A qualitative study of zoonotic risk factors among rural communities in southern China. Int. Health 2020, 12, 77-85. [CrossRef]

127. Säde, E.; Murros, A.; Björkroth, J. Predominant enterobacteria on modified-atmosphere packaged meat and poultry. Food Microbiol. 2013, 34, 252-258. [CrossRef]

128. Mouttotou, N.; Ahmad, S.; Kamran, Z.; Koutoulis, K.C. Prevalence, Risks and Antibiotic Resistance of Salmonella in Poultry Production Chain, in: Current Topics in Salmonella and Salmonellosis. InTech 2017. [CrossRef]

129. Shang, K.; Wei, B.; Kang, M. Distribution and dissemination of antimicrobial-resistant Salmonella in broiler farms with or without enrofloxacin use. BMC Vet. Res. 2018, 14, 257. [CrossRef]

130. Chen, J.; Xing, X.K.; Zhang, L.C.; Xing, Y.M.; Guo, S.X. Identification of Hortaea werneckii Isolated from Mangrove Plant Aegiceras comiculatum Based on Morphology and rDNA Sequences. Mycopathologia 2012, 174, 457-466. [CrossRef]

131. Ai, W.; Wei, X.; Lin, S.; Wang, Z.; Tu, Z.; Yang, X.; Zhou, X.; Li, J.; Liu, Y. Guignardins AeF, spirodioxynaphthalenes from the endophytic fungus Guignardia sp. KcF8 as a new class of PTP1B and SIRT1 inhibitors. Tetrahedron 2014, 70, 5806-5814. [CrossRef]

132. Bergelson, J.M.; Cunningham, J.A.; Droguett, G.; Kurt-Jones, E.A.; Krithivas, A.; Hong, J.S.; Horwitz, M.S.; Crowell, R.L.; Finberg, R.W. Isolation of a common receptor for coxsackie B viruses and adenoviruses 2 and 5. Science 1997, 275, 1320-1323. [CrossRef]

133. Marjomäki, V.; Turkki, P.; Huttunen, M. Infectious Entry Pathway of Enterovirus B Species. Viruses 2015, 7, 6387-6399. [CrossRef] [PubMed]

134. Linnakoski, R.; Reshamwala, D.; Veteli, P.; Cortina-Escribano, M.; Vanhanen, H.; Marjomäki, V. Antiviral agents from fungi: Diversity, mechanisms and potential applications. Front. Microbiol. 2018. [CrossRef]

135. Chang, J.; Block, T.M.; Guo, J.T. Antiviral therapies targeting host ER alpha-glucosidases: Current status and future directions. Antivir. Res. 2013. [CrossRef]

136. Ma, J.; Zhang, X.; Soloveva, V.; Warren, T.; Guo, F.; Wu, S.; Lu, H.; Guo, J.; Su, Q.; Shen, H.; et al. Enhancing the antiviral potency of ER $\alpha$-glucosidase inhibitor IHVR-19029 against hemorrhagic fever viruses in vitro and in vivo. Antivir. Res. 2018, 150, 112-122 [CrossRef]

137. González-Aldaco, K.; Torres-Reyes, L.A.; Ojeda-Granados, C.; José-Ábrego, A.; Fierro, N.A.; Román, S. Immunometabolic Effect of Cholesterol in Hepatitis C Infection: Implications in Clinical Management and Antiviral Therapy Concise Review. Ann. Hepatol. Off. J. Mex. Assoc. Hepatol. 2018, 17, 908-919. [CrossRef] [PubMed]

138. Lombardi, L.; Falanga, A.; Del Genio, V.; Palomba, L.; Galdiero, M.; Franci, G.; Galdiero, S. A boost to the antiviral activity: Cholesterol tagged peptides derived from glycoprotein B of Herpes Simplex virus type I. Int. J. Biol. Macromol. 2020, 162, 882-893. [CrossRef]

139. Ashkenazi, A.; Fairbrother, W.J.; Leverson, J.D.; Souers, A.J. From basic apoptosis discoveries to advanced selective BCL-2 family inhibitors. Nat. Rev. Drug Discov. 2017. [CrossRef]

140. Ebert, G.; Preston, S.; Allison, C.; Cooney, J.; Toe, J.G.; Stutz, M.D.; Ojaimi, S.; Scott, H.W.; Baschuk, N.; Nachbur, U.; et al. Cellular inhibitor of apoptosis proteins prevent clearance of hepatitis B virus. Proc. Natl. Acad. Sci. USA 2015, 112, 5797-5802. [CrossRef] [PubMed]

141. Shim, J.M.; Kim, J.; Tenson, T.; Min, J.Y.; Kainov, D.E. Influenza virus infection, interferon response, viral counter-response, and apoptosis. Viruses 2017, 9, 223. [CrossRef] [PubMed] 
142. Dai, J.R.; Carté, B.K.; Sidebottom, P.J.; Yew, A.L.S.; Ng, S.B.; Huang, Y.; Butler, M.S. Circumdatin G, a new alkaloid from the fungus Aspergillus ochraceus. J. Nat. Prod. 2001, 64, 125-126. [CrossRef] [PubMed]

143. Au, J.S.; Pockros, P.J. Novel Therapeutic Approaches for Hepatitis C. Clin. Pharmacol. Ther. 2013, 95, 78-88. [CrossRef]

144. Wheeler, N.C.; Jech, K.; Masters, S.; Brobst, S.W.; Alvarado, A.B.; Hoover, A.J.; Snader, K.M. Effects of genetic, epigenetic, and environmental factors on taxol content in taxus brevifolia and related species. J. Nat. Prod. 1992, 55, 432-440. [CrossRef] [PubMed]

145. Roopa, G.; Madhusudhan, M.C.; Sunil, K.C.R.; Lisa, N.; Calvin, R.; Poornima, R.; Zeinab, N.; Kini, K.R.; Prakash, H.S.; Geetha, N. Identification of Taxol-producing endophytic fungi isolated from Salacia oblonga through genomic mining approach. J. Genet. Eng. Biotechnol. 2015, 13, 119-127. [CrossRef]

146. Elavarasi, A.; Rathna, G.S.; Kalaiselvam, M. Taxol producing mangrove endophytic fungi Fusarium oxysporum from Rhizophora annamalayana. Asian Pac. J. Trop. Biomed. 2012, 2, S1081-S1085. [CrossRef]

147. Ryang, J.; Yan, Y.; Song, Y.; Liu, F.; Ng, T.B. Anti-HIV, antitumor and immunomodulatory activities of paclitaxel from fermentation broth using molecular imprinting technique. AMB Express 2019, 9. [CrossRef]

148. Rajamani, T.; Suryanarayanan, T.S.; Murali, T.S.; Thirunavukkarasu, N. Distribution and diversity of foliar endophytic fungi in the mangroves of Andaman Islands, India. Fungal Ecol. 2018, 36, 109-116. [CrossRef]

149. Pamphile, J.A.; dos Santos Ribeiro, M.A.; Polonio, J.C. Secondary metabolites of endophyte fungi: Techniques and biotechnological approaches. In Diversity and Benefits of Microorganisms from the Tropics; Springer International Publishing: New York, NY, USA, 2017; pp. 185-206. [CrossRef]

150. Deshmukh, S.K.; Society, M. Sunil Kumar Deshmukh. KAVAKA 2018, 13, 1-13.

151. Marmann, A.; Aly, A.H.; Lin, W.; Wang, B.; Proksch, P. Co-cultivation-A powerful emerging tool for enhancing the chemical diversity of microorganisms. Mar. Drugs 2014, 12, 1043-1065. [CrossRef] [PubMed]

152. Oh, D.C.; Kauffman, C.A.; Jensen, P.R.; Fenical, W. Induced production of emericellamides A and B from the marine-derived fungus Emericella sp. in competing co-culture. J. Nat. Prod. 2007, 70, 515-520. [CrossRef] [PubMed]

153. Zhu, F.; Chen, G.; Chen, X.; Huang, M.; Wan, X. Aspergicin, a new antibacterial alkaloid produced by mixed fermentation of two marine-derived mangrove epiphytic fungi. Chem. Nat. Compd. 2011, 47, 767-769. [CrossRef] 